\title{
Fatherhood in adolescence: prevalence and associated factors in a community sample of youngsters
}

\author{
Paternidade na adolescência: prevalência e fatores associados \\ em uma amostra comunitária de jovens
}

Milene Maria Saalfeld de Oliveira ${ }^{1}$

Jerônimo Costa Branco ${ }^{2}$

Luciano Dias de Mattos Souza ${ }^{1}$

Ricardo Azevedo da Silva ${ }^{1}$

Diogo Rizzato Lara ${ }^{3}$

Denise Marques Mota ${ }^{1}$

Karen Jansen ${ }^{1}$

${ }^{1}$ Programa de PósGraduação em Saúde e Comportamento,

Universidade Católica

de Pelotas. R. Gonçalves

Chaves 373, Centro. 96015

560 Pelotas RS Brasil.

mileneped@yahoo.com

${ }^{2}$ Centro Universitário

Franciscano.

${ }^{3}$ Departamento de Ciências

Fisiológicas, Faculdade

de Biociências, Pontifícia

Universidade Católica do

Rio Grande do Sul.

\begin{abstract}
This article aims to assess the prevalence of fatherhood in adolescence (FA) and associated factors in a community sample of 14 to 35 year-old men. Cross-sectional population-based study realized in the urban area of the city of Pelotas-RS, Brazil. The sample was selected by clusters, according to the city census. This sub-study only comprised sexually active men. Data were collected using a self-administered questionnaire in the participants' homes. The sample was composed for 934 men. The prevalence of fatherhood in adolescence was $8 \%(n=75)$. We verified higher prevalence of FA among those that reported paternal absence $(p<0.001)$, those that had lived with stepfather $(p=0.044)$, and among those that had sexual debut before the age of $14(p=0.011)$. Paternal absence, have lived with a stepfather, and early sexual experience are associated factors to fatherhood in adolescence.
\end{abstract}

Key words Adolescent, Fatherhood, Sexual behavior
Resumo O artigo tem por objetivo avaliar a prevalência de paternidade na adolescência (PA) e fatores associados em uma amostra comunitária de homens de 14 a 35 anos. Estudo transversal de base populacional realizado na zona urbana de Pelotas/RS, Brasil. A seleção amostral foi realizada por múltiplos estágios, considerando a divisão censitária do município. Neste estudo foram incluídos indivíduos do sexo masculino e sexualmente ativos. Os dados foram coletados através de questionário autoaplicável nos domicílios dos participantes. A amostra do estudo foi composta por 934 homens. A prevalência de paternidade na adolescência foi de $8 \%(n=75)$. Verificou-se maior prevalência de PA entre aqueles que relataram ausência paterna na infância $(p<0,001)$, aqueles que viveram com padrasto $(p=0,044) e$ entre aqueles que tiverem o início da vida sexual antes dos 14 anos. Conclusões: A ausência paterna e o convívio com padrasto na infância, bem como a iniciação sexual precoce são fatores associados à paternidade na adolescência.

Palavras-chave Adolescente, Paternidade, Comportamento sexual. 


\section{Introduction}

The teen pregnancy is not a recent phenomenon in the history of mankind, having had several of its causes described ${ }^{1,2}$. The issue is widely discussed in the scientific world as a predominantly female phenomenon, with gaps in the literature concerning the adolescent father, still to be investigated. Most of the studies use program samples and initiatives focused on the mother and the baby. Therefore, much data regarding the Fatherhood in the Adolescence (FA) are difficult to be interpreted due to the fact that the information was provided by the partners, not providing the male perspective and the family circumstances in which adolescents are inserted ${ }^{1,3}$.

The sexuality and the reproduction are intrinsic and fundamental to the human being, transcending the biopsychosocial aspects, being influenced by personal and family beliefs and, also, by cultural norms ${ }^{4}$. The adolescent should establish his sexual identity and face the emotional turmoil caused by the sexual desire 4 . The society, in a double message, demands from the young girls postponing motherhood for the adult age, repressing their desires for the birth control $^{4,5}$. However, male adolescents are expected to early express and satisfy their sexual desires, thus, with a significant difference between the genders, due to the sexual activity of the adolescent being a requirement for the acknowledgment of his masculinity, as it is acceptable that he has multiple sexual experiences ${ }^{4,5}$.

Researches show that men have started their sexual life in the adolescence (aged 10 to 19 years according to the World Health Organization). Many times this leads them to be involved in risky intercourses, which result may be the pregnancy of the partner ${ }^{4,5}$. The international literature describes the prevalence of the FA of 3,4\% - 21,4\%, ranging according to the socioeconomic profile of each place ${ }^{2}$. In Brazil, we found in two studies the prevalence of $6,3 \%{ }^{5}$ and $11 \%{ }^{6}$.

Considering that the birth of a child requires the involvement of three people, we call attention to the fact that the literature should contemplate the men as well, expanding the issue through scientific evidences which have been observed. Becoming a father at adolescence may cause a big impact in the life of one, as at the same time he will have to play the role of a father and of an adolescent. Thus, it is an important moment of transition to the adult life ${ }^{4}$.

This paper had as its main purpose describing the prevalence of fatherhood in the adoles- cence and the factors associated to it, based on a men community sample aged 14 to 35 years in a city in southern Brazil.

\section{Method}

Cross-sectional, population-based study carried out in the city of Pelotas-RS, Brazil, with a target population of young men aging between 14 and 35. This work is part of a bigger study called "Study of Temperament and Psychiatric Disorders in the Interface between Psychiatry, Psychology and Neurosciences", including the evaluation of both sexes. However, in this section only the male individuals who have already had some sexual activity were included. The sample selection was performed by multistage clusters, considering a population of approximately 97 thousand people in this age group and the current census division of the city in 495 areas, in which 83 were drawn. The data were provided by the Instituto Brasileiro de Geografia e Estatística (Brazilian Institute of Geography and Statistics) ${ }^{7}$.

The calculation of the sample size to check the prevalence of fatherhood in the adolescence and possible associations were based on the following parameters: confidence level of 95\%; power of $80 \%$; increase for losses and denials of $10 \%$ and increase for multivariable analysis of $15 \%$. Thus, the biggest estimated sample $n$ was seen in the calculation of prevalence, in which there was a consideration of $11 \%$ of fatherhood in adolescence, with an acceptable error of three percentage points, resulting a necessary sample of 460 individuals.

A pilot study was also performed in four areas which have not been drawn to be included in the research, with the purpose of adding practical and experiential practices to the training, as well as testing the study logistics and promoting the necessary changes.

After identifying the households and the possible members of the sample, those who agreed to join the study were visited at their homes for the application of the instruments, performed among June 2011 to February 2014. The interviewers were students from the psychology, medicine and physiotherapy courses, properly trained for the data collection.

The data collection used a digital instrument with sociodemographic questions, fatherhood characteristics and sexual behavior. In the sociodemographic category the following variables were included: age, skin color, education level 
of the householder, economic indicator ${ }^{8}$, years studying, marital status and present job; of family structure: separated parents, father's absence (not having lived with the father until turning 18) and if lived with stepfather for, at least, one month; while in terms of fatherhood characteristics there were the following variables: age when the first child was born, if the child was planned and if the father currently lives with the child. Besides this, a self-administered instrument was used to identify sexual behavior comprising the variables: age when he had the first intercourse (early beginning was considered when it happened before 14 years of age), use of contraceptive and/or protection method and if had ever been physically forced into an intercourse. Fatherhood in adolescence (outcome this study) was assessed using self-reporting of fatherhood before 20 years old.

This data collection was set in notebooks, using a data entry program Epi-Info 6.04d. A backup was daily performed with the collected data and they were transferred to the SPSS 13.0. In this software the so-called data cleaning, recoding of interest variables and data crude analysis was held. For adjusted analysis we used the Stata 11 program.

The description of the characteristics of the sample and fatherhood adolescence - when the child was born before the father have twenty years old - was presented through absolute and relative frequency. In order to check factors associated to fatherhood in the adolescence, a chi-square test was used. The data adjusted analysis was made by Poisson regression. In order to do so, an analysis hierarchical model was set, in which the first level comprised the demographic variables, the second the family structure variables and the third by variables concerning sexual behavior. In the adjusted analysis the variables with p-value $<0.20$ in the crude analysis were included. The same criterion was set to keep the model for the next hierarchical level. After adjustment, statistically significance was considered when $\mathrm{p}$-value $<$ 0.05 .

This study respected all the ethical principles established by the Health National Counsel in the Resolution No 196 from October 10th, 1996, guaranteeing the right to confidentiality of data and the care in the usage of the information in the written assignments, so that the participants may not be identified. Only the individuals who have signed the study consent agreement were included or when the agreement was signed by the one responsible for the individual.
The Project was financed by the publication of the Programa de Apoio a Núcleos de Excelência (Support Program to Excellence Centers) (PRONEX) and the Fundação de Amparo à Pesquisa do Estado do Rio Grande do Sul (Foundation of Support to Research of Rio Grande do Sul State) (FAPERGS). Approved by the Ethics Committee from the Catholic University of Pelotas.

\section{Results}

The study sample comprised 2344 subjects. Females $(\mathrm{n}=1273)$ and those who have not had their sexual debut $(n=137)$ were excluded. There was a total of 934 men left, aged between 14 to 35 years. The sociodemographic characteristics of the sample are described in Table 1.

Concerning the family structure, $35.8 \%$ had separated parents, $46.0 \%$ mentioned the absence of the father and $17.9 \%$ lived with their stepfather (Table 2). In terms of sexual behavior, 13.3\% had their sexual debut before they were 14 years old, $18.5 \%$ do not use any type of contraceptive/ protection method and $3.0 \%$ reported being forced to have intercourse (Table 3). Besides this, it was noticed that the absence of the father is associated to early sexual debut (PR 2.32; 95\% CI $1.42-3.79 ; \mathrm{p}<0,001)$.

The prevalence of fatherhood in adolescence was of $8.0 \%(n=75)$. Among these, $25.4 \%$ planned having the child; $46.5 \%$ currently live with their child, $26.8 \%$ have already lived but do not live anymore with the child and $26.8 \%$ never lived with their child. In the crude analysis, the proportion of fatherhood in adolescence was bigger among youngsters that have skin color other than white $(p=0.007)$, those of lower economic indicator $(\mathrm{p}<0.001)$, in which the householder had an education level lower than high school level $(\mathrm{p}<0.001)$, youngsters that did not complete high school $(\mathrm{p}<0.001)$ and who had a partner/companionship ( $\mathrm{p}<0.001)$.

Concerning the family structure aspects, having separated parents $(p=0.007)$, the absence of the father during childhood or adolescence $(\mathrm{p}=$ 0.001 ), and having lived for at least one month with a stepfather increased in about twice as much the proportion of FA in the crude analysis of the data $(\mathrm{p}=0.009)$ (Table 2$)$.

Concerning the variables in terms of sexual behavior, in the crude analysis fatherhood during adolescence was two times more prevalent among the men who had their sexual debut before reaching the age of $14(\mathrm{p}=0.001)$ (Table 3$)$. 


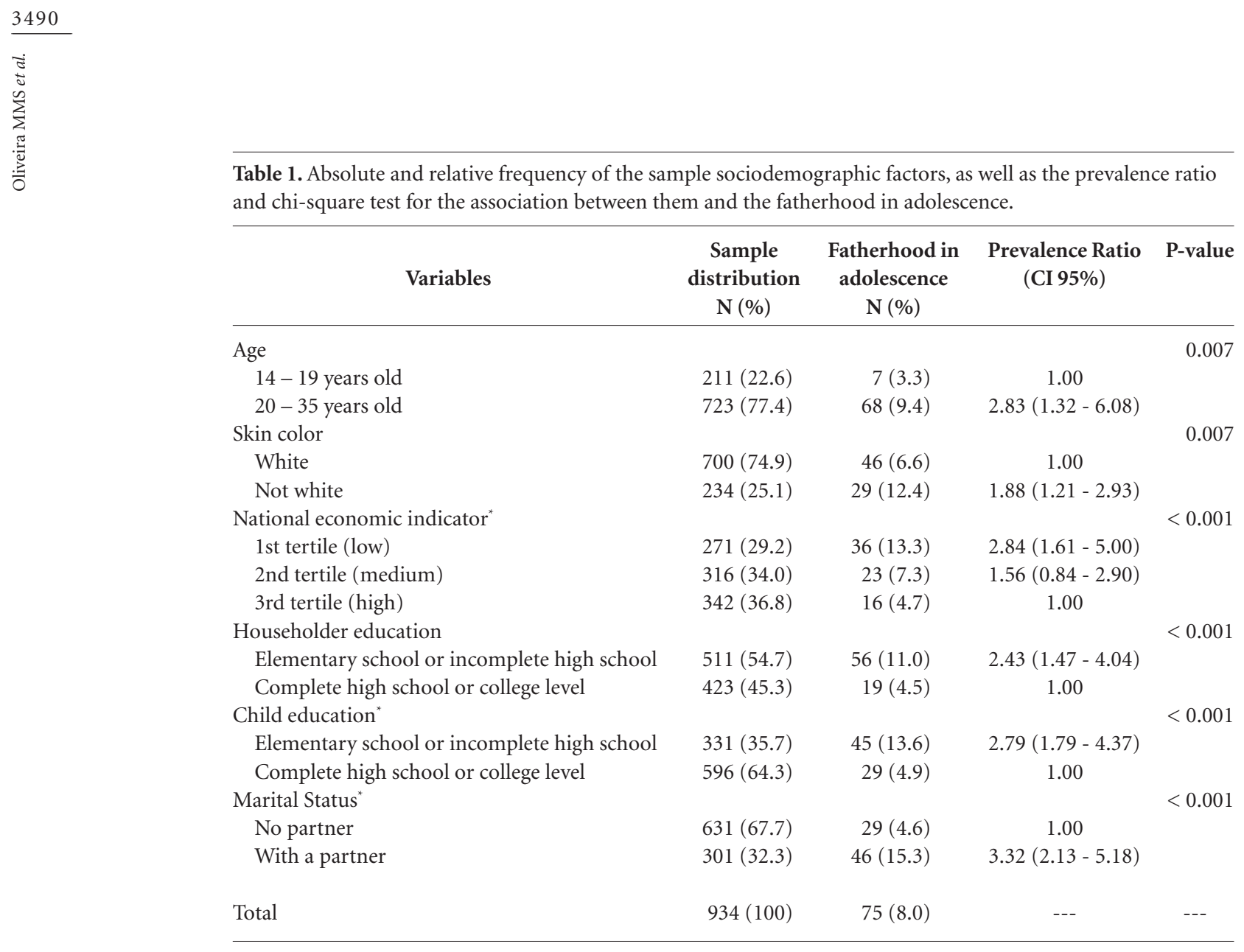

*Variables with missing.

Table 2. Absolute and relative frequency of the family structure characteristics, as well as the prevalence ratio and the chi-square test for the association between them and the fatherhood in adolescence.

\begin{tabular}{|c|c|c|c|c|}
\hline Variables & $\begin{array}{c}\text { Sample } \\
\text { distribution } \\
\mathrm{N}(\%)\end{array}$ & $\begin{array}{c}\text { Fatherhood in } \\
\text { adolescence } \\
\mathrm{N}(\%)\end{array}$ & $\begin{array}{l}\text { Prevalence Ratio } \\
\quad \text { (CI 95\%) }\end{array}$ & P-value \\
\hline Separated parents ${ }^{*}$ & & & & 0.007 \\
\hline No & $598(64.2)$ & $37(6.2)$ & 1.00 & \\
\hline Yes & $333(35.8)$ & $38(11.4)$ & $1.84(1.20-2.84)$ & \\
\hline Father Absence ${ }^{\#}$ & & & & $<0.001$ \\
\hline No & $504(54.0)$ & $24(4.8)$ & 1.00 & \\
\hline Yes & $430(46.0)$ & $51(11.9)$ & $2.49(1.56-3.98)$ & \\
\hline Lived with stepfather ${ }^{*}$ & & & & 0.009 \\
\hline No & $765(82.1)$ & $52(6.8)$ & 1.00 & \\
\hline Yes & $167(17.9)$ & $22(13.2)$ & $1.94(1.21-3.09)$ & \\
\hline Total & $934(100)$ & $75(8.0)$ & --- & --- \\
\hline
\end{tabular}

"Variables with missing." Did not live with the father until eighteen years old.

In terms of family structure, when adjusted for the sociodemographic variables, the paternal absence $(\mathrm{p}<0.001)$ and having lived with the stepfather $(\mathrm{p}=0.044)$ were associated with FA.
However, the sexual debut before the age of 14 remained as an associated factor for the outcome $(\mathrm{p}=0.011)$ (Table 4). 
Table 3. Absolute and relative frequency of the sexual behavior variables, as well as the prevalence ratio and the chi-square test for the association between them and the fatherhood in adolescence.

\begin{tabular}{|c|c|c|c|c|}
\hline Variables & $\begin{array}{c}\text { Sample } \\
\text { distribution } \\
\mathrm{N}(\%)\end{array}$ & $\begin{array}{l}\text { Fatherhood in } \\
\text { adolescence } \\
\mathrm{N}(\%)\end{array}$ & $\begin{array}{l}\text { Prevalence Ratio } \\
\quad \text { (CI 95\%) }\end{array}$ & P-value \\
\hline Early sexual debut $(<14 \text { years })^{*}$ & & & & 0.001 \\
\hline No & $804(86.1)$ & $53(6.6)$ & 1,00 & \\
\hline Yes & $124(13.3)$ & $19(15.3)$ & $2.32(1.42-3.79)$ & \\
\hline Contraceptive method /protection ${ }^{*}$ & & & & 0.002 \\
\hline No method & $172(18.5)$ & $20(11.6)$ & $2.05(1.21-3.46)$ & \\
\hline Practice of contraception & $140(15.1)$ & $19(13.6)$ & $2.39(1.41-4.05)$ & \\
\hline Practice of protection & $617(66.4)$ & $35(5.7)$ & 1.00 & \\
\hline Forced to have sex ${ }^{*}$ & & & & 0.866 \\
\hline No & $901(97.0)$ & $72(8.0)$ & 1,00 & \\
\hline Yes & $28(3.0)$ & $3(10.7)$ & $1.34(0.50-3.99)$ & \\
\hline Total & $934(100)$ & $75(8.0)$ & --- & --- \\
\hline
\end{tabular}

"Variables with missing.

Table 4. Poisson regression for data adjusted analysis in relation to fatherhood in adolescence, presented through prevalence ratio, confidence intervals and $\mathrm{p}$-value.

\begin{tabular}{lrr}
\hline \multicolumn{1}{c}{ Variables $^{*}$} & $\begin{array}{c}\text { Prevalence Ratio } \\
(\text { CI 95\%) }\end{array}$ & \multicolumn{1}{c}{ P-value } \\
\hline $1^{\text {st }}$ hierarchical level & $3.20(2.27-4.49)$ & $<0.001$ \\
$\quad$ Age between 20 and 35 & $1.29(1.07-1.56)$ & 0.008 \\
$\quad$ Skin color no white & & \\
$\quad$ National economic indicator & $1.97(1.45-2.65)$ & $<0.001$ \\
$\quad 1^{\text {st }}$ tertile (low) & $1.39(1.03-1.88)$ & 0.033 \\
$\quad 2^{\text {nd }}$ tertile (medium) & $1.19(0.94-1.50)$ & 0.139 \\
$\quad$ Householder with elementary school or incomplete high school education & $2.05(1.65-2.55)$ & $<0.001$ \\
$\quad$ Youngster with elementary school or incomplete high school education & $1.79(1.46-2.18)$ & $<0.001$ \\
$\quad$ Marital status, having a partner & $1.13(0.93-1.37)$ & 0.212 \\
$2^{\text {nd }}$ hierarchical level & $2.53(1.98-3.23)$ & $<0.001$ \\
$\quad$ Having separated parents & $1.23(1.00-1.50)$ & 0.044 \\
$\quad$ Paternal Absence & $1.32(1.06-1.63)$ & 0.011 \\
$\quad$ Having lived with the stepfather & & \\
$3^{\text {rd }}$ hierarchical level & & \\
$\quad$ Early sexual debut & & \\
\hline
\end{tabular}

"The reference categories of the variables were omitted.

\section{Discussion}

In this sample of 934 men aging between 14 to 35 years old with sexual debut we confirmed the hypothesis that adolescents of lower economic classification, skin color other than white and who have a partner/companionship tend to anticipate the fatherhood. This study also confirmed the hypothesis that fatherhood in the adolescence is associated to early sexual debut, absence of the father and surrogate in the family structure.

When analyzing the association between adolescence, sexuality and pregnancy, it is necessary to observe the uniqueness of each adolescent suffering socioeconomic and cultural influences, which are faced differently in certain places and in each family, which does not allow us to make generalizations concerning the reproductive be- 
havior. Pregnancy and fatherhood are discussed as an unwanted problem and seen as early in medical, social and legal terms ${ }^{1,5,6,9}$. But what really matters is the following: a problem to whom? We noticed in our research that $25.4 \%$ of the adolescents planned having the child. Many times it is through fatherhood that the adolescent has the chance to enter the so called adult world with the real meaning of being a man ${ }^{4,10,11}$. However, this is not the rule, considering that most of the respondents became a father as a result of the binomial vulnerability and risk, such as: being of lower socioeconomic classification, having skin color other than white, with early quitting from school activities and belonging to a family whose householder has low education level ${ }^{12-15}$.

Evidences point out that social, economic and individual factors are interrelated and influence the prevalence of FA. Some factors are highlighted, such as the paternal deprivation ${ }^{12,16}$, poverty ${ }^{6}$, lack of access to adequate educational services $^{13,14}$, type of relationship with the partner/ companionship, desire for intimacy and hope concerning the future ${ }^{1,10,11}$.

Studies say that it is important to evaluate the racial differences in the reproductive history of the adolescents. The aspect skin color has been described as an important social marker, especially because the not white population has been emphasized as socially excluded ${ }^{15}$. In this sample, having the not white skin color presented a higher probability of being a father during adolescence. Although in another study the skin color was not associated to male parenthood ${ }^{6}$.

Education prevents risky sexual behavior and stimulates the practice of sex responsibly, increasing individual awareness and opportunities. It enables the questioning of rules and therefore helps capturing the due processing of the information acquired, necessary in order to make decisions. In this study, we observed that youngsters with incomplete high school studies presented a higher probability of becoming adolescents fathers. The reviewed literature says that the percentage of youngsters at the university who experienced fatherhood in adolescence is low $^{5,13,17-21}$.

Studies report that the age of the sexual debut is a determining risk factor for the teen pregnan$\mathrm{cy}^{5,15,19,22}$, considering the late sexual debut is a strong pillar to prevent the outcome. The average age for the sexual debut was of 15.5 years old in our research according to the literature ${ }^{15,22}$. It was observed that the early sexual debut has increased the probability to the outcome of the study.
The literature suggest that sexually abused teens have more sexual partners and earlier sexual debut, besides being less likely to use contraceptive methods, all of these associated to fatherhood in adolescence ${ }^{18,23-26}$. However, the hypothesis of relation to sexual abuse and fatherhood in adolescence was not confirmed in this work, probably due do the small number of subjects who reported having been forced to intercourse.

The Child and Adolescent Statute establishes the right to fatherhood; and the Law n. 8560/ 1992 concerning the fatherhood investigation, grants the mothers the right to demand the fathers to assume the paternity of their children, especially as it understands it is crucial for the child to know his/her filiation ${ }^{27}$. In the present study, not having lived with the father, and having a stepfather was associated to the outcome after the adjustment for sociodemographic variables ${ }^{28}$. However, the absence of the father is highlighted as a risk factor for early sexual debut, according to what was pointed out in another study ${ }^{23}$.

As this is a cross-sectional study in which some data were retrospective, some variables may have been influenced by the recall bias of the respondents. Besides this, the prevalence of FA may be underestimated for two reasons: some men do not know they are fathers and also because this study sample comprised youngsters aging 14 years or above, and some may become fathers before they reach 20 . On the other hand, the population outline is innovative in studies on the issue and is a strong point in this work, as it demands methodological criteria in the sample selection of clusters. Another positive point of the present study is that it was developed with information from the individuals themselves, as most of the data in the literature are provided by the partners.

This article aimed to focus on fatherhood in adolescence, contributing in the pursuit for new knowledge and answers to an issue which is often seen as a "problem". Although considered as a cause for a great impact in the life of a youngster, the fatherhood should be understood as a possibility on these young people's lives, mainly to those in a situation of social vulnerability. The sexual debut is a characteristic typical for this age whose early debut becomes a factor associated to the outcome. We call attention for the necessity of prevention strategies and investments on support networks which can educate the adolescent to a safe practice of his sexuality, bringing to this debate the meaning that a responsible fatherhood plays in the rise to maturity. 


\section{Collaborations}

MMS Oliveira worked in analysis and interpretation of data, writing of article and approved the version to be published; JC Branco, LDM Souza and RA Silva worded in conception and design of the study, drafting the article and approval of the version to be published; DR Lara worked in conception and design of the study, critical review and approval of the version to be published; DM Mota and $\mathrm{K}$ Jansen worked in analysis and interpretation of data, drafting the article and approval of the version to be published.

\section{Acknowledgements}

The project was financed by the Programa de Apoio a Núcleos de Excelência (PRONEX) and the Fundação de Amparo à Pesquisa do Estado do Rio Grande do Sul (FAPERGS).

\section{References}

1. Lyra J. Paternidade na Adolescência: Percorrendo a bibliografia [tese]. Recife: Universidade Federal de Pernambuco; 1997.

2. Levandowski DC. Paternidade na adolescência: uma breve revisão de literatura internacional. Estud psicol 2001; 6(2):195-209.

3. Luz AM, Berni NI. Paternity process in the adolescence. Rev Bras Enferm 2010; 63(1):43-50.

4. Françoso LA, Gejer D, Reato L. Sexualidade e Saúde Reprodutiva na Adolescência. São Paulo: Atheneu; 2001.

5. Marinho LFB, Aquino EML, Almeida MCC. Contraceptive practices and sexual initiation among young people in three Brazilian State capitals. Cad Saude Publica 2009; 25(Supl. 2):227-239.

6. Gigante DP, Barros FC, Veleda R, Gonçalves H, Horta BL, Victora CG. Maternity and paternity in the Pelotas birth cohort from 1982-2004-5, Southern Brazil. Rev Saude Publica 2008; 42(Supl. 2):42-50.

7. Instituto Brasileiro de Geografia e Estatística (IBGE). Censo demográfico de 2000. [acessado 2015 out 2]. Disponível em: http://www.ibge.gov.br/home/estatistica/ populacao/default_censo_2000.shtm

8. Barros AJ, Victora C. Indicador Econômico para o Brasil baseado no censo demográfico de 2000. Rev Saude Publica 2005; 39(4):523-529.

9. Gonzalez E. La Paternidade en el Adolescente: un problema social. Arch. venez. pueric. pediatr. 2009; 72(3): 86-91.

10. Heilborn ML, Salem T, Rohden F, Brandão E, Knauth D, Víctora C, Aquino E, McCallum C, Bozon M. Aproximações socioantropológicas sobre a gravidez na adolescência. Horiz. Antropol. 2002; 8(17):13-45.

11. Dias AD, Aquino E. Teenage motherhood and fatherhood: observations in three cities of Brazil. Cad Saude Publica 2006; 22(7):1447-1458.

12. Sganzerla IM, Levandowski DC. Paternal absence and its repercussions on the adolescent: analyzing the literature. Psicol. rev. (Belo Horizonte) 2010; 16(2):295-309.

13. Schelemberg JM, Pereira LD, Grisard N, Hallal ALC. Características socioeconômicas e psicossociais do pai adolescente. ACM arq. catarin. Med. 2007; 36(2):62-68.

14. Almeida AFF, Hardy E. Gender vulnerability for parenthood among male adolescents. Rev Saúde Públ 2009; 41(4):565-572.

15. Borges ALV, Schor N. Sexual debut in adolescence and gender relations:a cross-sectional study in São Paulo, Brazil, 2002. Cad Saude Publica 2005; 21(2):499-507.

16. Freitas WMF, Coelho EAC, Silva ATMC. Fatherhood: the male experience from a gender focus. Cad Saude Publica 2007; 23(1):137-145.

17. Paula ER, Bittar CM, Silva MAI, Cano MAT. Paternity in adolescence and its meaning among Young academics that lived it. UNIPAM - Rev Mineira de Ciên Saúde 2010; (2):28-42.

18. Moraes CL, Cabral C, Heilborn ML. Magnitude and characterization of sexual coercion experienced by young adults in three Brazilian state capitals: Porto Alegre, Rio de Janeiro, and Salvador. Cad Saude Publica 2006; 22(7):1493-1504.

19. Cabral C. Teenage contraception and pregnancy from the perspective of young low-income fathers in a slum area in Rio de Janeiro. Cad Saude Publica 2003; 19(Supl. 2):283-292. 
20. Rocha C, Horta B, Pinheiro R. Use of contraceptive methods by sexually active teenagers in Pelotas, Rio Grande do Sul State, Brazil. Cad Saude Publica 2007; 23(12):2862-2868.

21. Martins LBM, Paiva LC, Osis MJD, Sousa MH, Pinto Neto AM, Tadini V. Knowledge of contraceptive methods among adolescent students. Rev Saude Publica 2006; 40(1):57-64

22. Hugo TDO, Maier VT, Jansen K, Rodrigues CEG, Cruzeiro ALS, Ores LC, Pinheiro RT, Silva R, Souza LDM Fatores associados à idade da primeira relação sexual em jovens: estudo de base populacional. Cad Saude Publica 2011; 27(11):2207-2214.

23. Khurana A, Gavazzi S. Juvenile delinquency and adolescent fatherhood. Int J Offender Ther Comp Criminol 2010; 55(5):756-770.

24. La Taillade JJ, Hofferth S, Wight VR. Consequences of fatherhood for young mens's relationships. Res Hum Dev 2010; 7(2):103-122.

25. Anda R, Chapman DP, Felitti VJ, Edwards V, Williamson DF, Croft JB, Giles WH. Adverse Childhood Experiences and Risk of paternity in teen pregnancy. Obstet Gynecol 2002; 100(1):37-45.

26. Rossetto MS, Schermann LB, Béria JU. Maternidade na adolescência: indicadores emocionais negativos e fatores associados em mães de 14 a 16 anos em Porto Alegre, RS, Brasil. Cien Saude Colet 2014; 19(10):42354246.

27. Brasil. Lei 8.069, de 13 de julho de 1990. Dispõe sobre o Estatuto da Criança e do Adolescente e dá outras providências. Diário Oficial da União 1990; 16 jul.

28. Patias ND. Factors making adolescent vulnerable to pregnancy. Adolesc Saúde 2011; 8(2):40-45.

Artigo apresentado em 14/08/2014

Aprovado em 19/06/2015

Versão final apresentada em 21/06/2015 